\title{
Международные отношения
}

\section{УДК-327}

DOI: 10.17072/2218-1067-2021-3-77-87

\section{ПОЛИТИЧЕСКОЕ ЗНАЧЕНИЕ КРЫМА ДЛЯ УКРАИНЫ В 1991-2014 ГГ.}

\section{С. Е. Киевец}

Киевеи Семен Евгеньевич, аспирант, Аспирантская школа по международным отношениям и зарубежным региональным исследованиям, Национальный исследовательский университет «Высшая школа экономики», Россия, Москва. E-maiL: KievecSemyon@yandex.ru (ORCID: 0000-0002-8943-4416).

\begin{abstract}
Аннотация
Рассматривается политическое значение Крыма в составе Украины в 1991-2014 гг. и анализируются основные проблемы во взаимоотношениях Киева и Симферополя. На основе обширной документальной базы делается вывод о неправовом включении Республики Крым в 1990-х гг. в состав украинского государства. Анализируется деструктивное влияние русского и русскоязычного населения полуострова на формирование украинской государственности. Определяется роль пророссийских организаций и русскоязычного населения в выходе Крыма из состава Украины. Изучается роль Черноморского флота для украинского государства, который использовался как инструмент давления на Россию для повышения статуса страны в глазах НАТО. Оценивается вклад Крыма в экономику Украины, отмечается высокая роль рекреационного сектора и определяются основные отрасли промышленности и сельского хозяйства АР Крым. В статье делается вывод о неизбежности конфликта между Киевом и Симферополем и присоединения Крыма к России, что обусловлено противоречивой политикой украинских властей. Прослеживается отсутствие значимости Крымского полуострова для Украины с точки зрения экономического развития, формирования единой украинской нации и обеспечения безопасности страны.
\end{abstract}

Ключевые слова: Автономная Республика Крым; Украина; Россия; аннексия; русскоязычное население; Черноморский флот; экономика.

Украинский кризис и последовавшая за ним «Крымская весна» стали одними из поворотных событий на постсоветском пространстве со времени распада СССР в 1991 г. Украина, потеряв Крым и испытывая комплекс страны, «пострадавшей от агрессии России», определилась с главным вектором развития своей внешней политики. Сделав ставку на евроатлантическую интеграцию, она свела к минимуму экономические, политические, культурные и иные связи с Россией.

Россия, опираясь на итоги мартовского референдума 2014 г. в Крыму, в одностороннем порядке объявила о вступлении полуострова в Российскую Федерацию на правах субъекта, не согласовав данный шаг с ЕС, США и их партнерами. Запад, в свою очередь, проявил солидарность с Украиной, начав санкционную политику в отношении России.

Вхождение Крыма в состав РФ предоставило Киеву возможность требовать от Запада санкций против России, солидарности с Украиной как «жертвой» российских «имперских амбиций». Киев закрепил на международном уровне обвинения в адрес Российской Федерации в «оккупации» Крымского полуострова. Несомненное возвращение Крыма в состав Украины стало неотъемлемой частью национальной идеологии страны. Киев демонстративно не готов мириться с потерей Крымского полуострова и постоянно декларирует свои стремления предпринимать некие действия по его возврату.

В связи с вышеизложенным, цель статьи - рассмотрение взаимоотношений Украины и АР Крым в период до 2014 г., что, в свою очередь, должно помочь определить значение Крыма в политике Киева в отношении России.

(C) Киевец С. Е., 2021 


\section{Правовой статус Крыма и его насильственное включение в состав Украины}

Противоречивая с точки зрения законодательства процедура перехода Крымской области под юрисдикцию Украинской ССР в 1954 г. заложила предпосылки для дальнейших дискуссий между Россией и Украиной о принадлежности Крыма.

В соответствии с указом президиума Верховного Совета СССР полуостров был передан Украинской ССР 19 февраля 1954 г. ${ }^{1}$. Однако процесс передачи Крыма противоречил положениям Конституции РСФСР 1937 г., поскольку Основной закон РСФСР не наделял Верховный Совет РСФСР полномочиями на изменение границ ее административно-территориальных образований (33-я статья) $)^{2}$. Президиум Верховного Совета СССР, в свою очередь, также не обладал соответствующей компетенцией изменять территориальные границы Крымской области, что отражено в ст. 49 Конституции СССР 1936 г.³.

В то же время указ президиума Верховного Совета СССР не распространялся на Севастополь, который являлся самостоятельным административно-хозяйственным центром и имел статус города республиканского значения. На момент передачи Крымской области в 1954 г. Севастополь не входил в ее состав, что подтверждает его принадлежность де-юре РСФСР (Президиум Верховного Совета РСФСР, 1948) ${ }^{4}$. Проблема принадлежности Крыма таким образом была заложена посредством приобретения юридической силы указом президиума Верховного Совета СССР, противоречащим Конституциям СССР и РСФСР, и возникла в международном информационном пространстве после распада СССР в 1991 г.

На референдуме в январе 1991 г. 93,3\% крымчан поддержали «воссоздание Крымской Автономной Советской Социалистической Республики (АССР) как субъекта СССР и участника Союзного договора» (Вишняков, 2011: 62). На всеукраинском референдуме, состоявшемся 1 декабря 1991 г., был одобрен «Акт провозглашения независимости Украины». Окончательная явка на всеукраинском референдуме в Крымской АССР и Севастополе составила 67,5 \% и 63,74 \%, при этом «Акт» подтвердило 54,19 и 57,07\% соответственно 5 . Низкая явка на референдуме в Крыму ставит под сомнение его легитимность, ведь две третьих граждан, проживающих на территории полуострова, проигнорировали голосование или его не поддержали. На референдуме был поставлен вопрос не о будущем статусе Крыма в рамках нового государства, а именно о независимости Украины (Вишняков, 2011: 65).

Опираясь на решения декабрьского референдума 1991 г., Украина в первой половине 1990-х гг., уже после распада СССР, фактически аннексировала Крым, что проявилось в эволюции общественно-политических настроений населения полуострова, о чем свидетельствует его общественнополитическое развитие.

Верховный Совет Украинской ССР, в феврале 1991 г. принял постановление «о восстановлении Крымской АССР в ее составе», исказив результаты всенародного голосования (Вишняков, 2011: 62-63). Дело в том, что на декабрьском референдуме 1991 г. поднимался вопрос именно о воссоздании Крымской АССР и подтверждении юрисдикции СССР на территории Крыма. Ни одно из этих положений впоследствии не было выполнено.

Украина осуществила перевод Крыма в свою юрисдикцию насильственным образом и вопреки ст. 3 Закона о выходе из состава СССР от 3 апреля 1990 г. Данная статья предусматривала, что в союзных республиках, имевших в своем составе автономные республики, «референдум должен был состояться отдельно в каждой автономии» ${ }^{6}$. Крымской АССР, обладавшей статусом автономной рес-

\footnotetext{
${ }^{1}$ О передаче Крымской области из состава РСФСР в состав УССР: Указ Президиума Верховного Совета СССР. Народный Фронт «Севастополь-Крым-Россия». URL: http://www.sevkrimrus.narod.ru/SevKrimRus/ZAKON/1954.htm (дата обращения: 29.07.2020).

2 Конституция (Основной Закон) Российской Советской Федеративной Социалистической Республики (утверждена постановлением Чрезвычайного XVII Всероссийского Съезда Советов от 21 января 1937 г.). Гарант-Сервис. URL: https://constitution.garant.ru/history/ussr-rsfsr/1937/red_1937/3959896/ (дата обращения: 13.12.2020).

3 Конституция (Основной закон) Союза Советских Социалистических Республик (утверждена постановлением Чрезвычайного VIII Съезда Советов Союза Советских Социалистических Республик от 5 декабря 1936 г.). Гарант-Сервис. URL: http://constitution.garant.ru/history/ussr-rsfsr/1936/red_1936/3958676/ (дата обращения: 13.12.2020).

${ }^{4} \mathrm{O}$ выделении города Севастополя в самостоятельный хозяйственный административно-хозяйственный центр: Указ Президиума Верховного Совета РСФСР. Федеральное архивное агентство. URL: http://krym.rusarchives.ru/dokumenty/ukazprezidiuma-verhovnogo-soveta-rsfsr-o-vydelenii-goroda-sevastopolya-v-samostoyatelnyy (дата обращения: 23.08.2020).

${ }_{5}^{5}$ Відомість про результати Всеукраїнського референдуму, 1 грудня 1991 р. Державна архівна служба Украйни. Ф. 1. Оп. 28. Спр. 144. Арк. 6. URL: https://old.archives.gov.ua/Sections/15r-V_Ref/index.php?11 (дата обращения: 10.12.2020).

${ }^{6}$ О порядке решения вопросов, связанных с выходом союзной республики из СССР: Закон СССР от 3 апр. 1990 г. № 1409 -I. Гарант. URL: https://base.garant.ru/6335629/\#friends (дата обращения: 01.12.2020).
} 
публики с января 1991 г., украинские власти не предоставили возможность проведения своего собственного референдума.

В то же время политический кризис, сопровождающийся усилением противоречий между крымским парламентом и президентом Крыма Ю. Мешковым, ослабил влияние крымских политиков на полуострове. Отсутствие конструктивного диалога среди крымских элит и формирования единой политической силы в Крыму, раскол внутри блока «Россия», получившего большинство мест в местном парламенте, предопределили усиление позиций Киева в Республике (Мацузато, 2009: 58-59).

Используя разногласия между исполнительной и законодательной властями в Крыму, президент Украины Л. Кучма преодолел противоречие между автономией и центром и вернул Республику Крым в правовое поле Украины. Некоторые указы и постановления крымских властей с 1991 г. по 1995 г., в том числе Конституция Крыма 1992 г. и должность президента Республики, введенная в 1994 г., были также упразднены. Первый и единственный президент Крыма Ю. Мешков, отличавшийся пророссийскими взглядами, был вынужден покинуть территорию полуострова и «бежать» в Москву (Мацузато, 2009: 61-62).

Таким образом, включение Крыма в состав Украины в середине 1990-х гг. являлось не результатом компромисса между крымской элитой, крымчанами и украинскими властями, а стало следствием решительных действий украинского президента Л. Кучмы.

С другой стороны, переход Крыма под юрисдикцию Украины в 1990-х гг. оказался возможным благодаря пассивной позиции России, которая, желая уклониться от российско-украинского территориального спора, не вмешивалась в разворачивающиеся политические события на полуострове и заняла позицию стороннего наблюдателя. Несмотря на позицию руководства страны, среди российских элит, к числу которых относились мэр Москвы Ю. Лужков и представители Госдумы С. Бабурин и Д. Рогозин, (Мальгин, 2012: 336), были распространены настроения в пользу включения Крыма в состав России.

Пассивная позиция российского руководства по Крыму в 1991 г. была обусловлена, с одной стороны, нежеланием РФ обострять сложные отношения с Украиной после распада СССР. Раздел Черноморского флота СССР и ядерное разоружение украинского государства имели первоочередное значение в российско-украинских отношениях, так как являлись важнейшей частью обеспечения безопасности России.

С другой стороны, в российском руководстве в 1990-е гг. было принято считать, что численное превосходство русского и русскоязычного населения в этническом и национальном составе населения Крыма должно было стать инструментом для поддержания дружественных отношений с Украиной посредством укрепления экономических, культурных и иных связей России с АР Крым. Время показало, что русская и русскоязычная часть населения Крыма в постсоветской Украине оказалась в роли заложников Киева и основой постоянного шантажа России украинским государством.

\section{Проблемы русскоязычного населения в Крыму в период до 2014 г.}

Среди всех регионов Украины АР Крым и г. Севастополь были единственными административно-территориальными единицами, в которых представители русского населения составляли существенное большинство. По данным украинской переписи населения 2001 г., 60,4\% резидентов Крыма являлись русскими, 24\% - украинцами и $10,2 \%$ - крымскими татарами. Характерной чертой населения Крыма являлся тот факт, что значительное большинство представителей нерусского населения признавало русский язык родным, в том числе 59,5\% украинцев АР Крым и 70,1\% украинцев, проживавших в Севастополе ${ }^{1}$. Однако, несмотря на численное превосходство русскоязычных граждан и распространенность русского языка среди крымчан, только при В. Януковиче в августе 2012 г. был принят закон, предоставивший русскому и крымско-татарскому языкам статус региональных 2 .

Сложный этнический состав Крыма предопределил его особую роль в политической жизни Украины. Численное превосходство русского и русскоязычного населения вызывало беспокойство среди украинских политических элит, поскольку, по их мнению, этническое преобладание русских в регионе обеспечивает предпосылки для возможного вмешательства России во внутренние дела Украины под предлогом сотрудничества с крымчанами.

\footnotetext{
${ }^{1}$ Всеукраинская перепись населения 2001. Государственный комитет статистики Украины. URL: http://2001.ukrcensus.gov.ua/rus/results/nationality_population/nationality_popul1/ (дата обращения: 20.05.2020).

${ }^{2}$ Про засади державної мовної політики: Закон України, 2012 г. Ліга Закон. URL: http://search.ligazakon. ua/__doc2.nsf/link1/T125029.html (дата обращения: 14.12.2020).
} 
Осознавая численное превосходство русскоязычного населения, украинские власти стремились извлекать выгоду из напряженной межнациональной ситуации в Крыму, которая сложилась в результате возвращения крымских татар. Их «преданность» Киеву позволила украинскому руководству использовать крымско-татарское движение в качестве «противовеса» интересам русского населения, проживавшего на полуострове (Мальгин, 2014). Земельный вопрос, различные политические взгляды стали причинами для обострения межнациональной ситуации, что приводило к конфликтным ситуациям между представителями крымских татар и русскоязычного населения (Никифоров, 2019: 732). Можно утверждать, что Киев «стравливал» крымских татар с русским и русскоязычным населением полуострова.

Славянское население АР Крым, в отличие от крымских татар, в постсоветский период всегда поддерживало идеи сближения с Россией. Свою позицию крымчане выражали на общеукраинских выборах. Жители полуострова на протяжении всего пребывания в составе Украины поддерживали политических лидеров и политические партии, которые выступали за углубление интеграции с Россией. На выборах президента Украины большинство граждан Крыма голосовали за Л. Кучму (1994 г.), П Симоненко (1999 г.), В. Януковича (2004 и 2010 гг.); на выборах народных депутатов предпочтение отдавалось «Коммунистической партии Украины», затем с 2006 г. - «Партии регионов». Партии, ставящие целью своей деятельности интеграцию с Европейским союзом и структурами НАТО, а также националистические партии, не отражавшие общественно-политические интересы и взгляды крымчан, не пользовались популярностью в Крыму (Ерохина, 2016).

Однако, учитывая складывающуюся ситуацию в 1990-х гг, русское население Крыма, в том числе и этнические украинцы, до 2014 г. чаще всего выступали в качестве сторонников расширения автономии АР Крым в составе Украины, а затем, уже на протяжении 2000-х гг. не теряли надежды на воссоединение с Россией.

Сопротивление русского и русскоязычного населения Крыма интеграции полуострова в состав Украины прошло несколько этапов. В 1994 г., по мнению около 80\% крымчан, предоставление юридической силы законам президента Крыма позволило бы ему проводить политику в интересах местного населения, сводя к минимуму деструктивную роль Киева. Восстановление Конституции Крыма от 1992 г, обеспечивавшей широкую автономию республике в составе Украины, также соответствовало интересам крымчан, поскольку перевело бы отношения с Киевом на договорную основу. Фактически Крым требовал федерального статуса. Движение Крыма в сторону «федерализации» отношений с центром вызвало беспокойство у киевских властей, и они не допустили потери контроля над общественно-политическим развитием республики (Мальгин, 2000: 109).

Общественно-политическое движение русскоязычного населения Крыма было подвержено перепадам в отношениях между Россией и Украиной. Резкая смена внешнеполитического курса украинского государства после прихода к власти В. Ющенко вызвала беспокойство крымчан. Акции националистически настроенных украинцев, поддерживавших стремление к членству в НАТО, способствовали росту пророссийских настроений среди жителей Крыма. «Оранжевая революция» привела к активизации деятельности радикальных пророссийских организаций на полуострове, среди которых можно отметить Народный фронт «Севастополь-Крым-Россия» и молодежную организацию «Прорыв» (Мальгин, 2012: 339-340).

В течение президентства В. Ющенко (2005-2010 гг.) в Крыму проводилась политика украинизации, целью которой являлось насильственное внедрение элементов украинской культуры в жизнь крымчан. Основная роль отводилась внедрению украинского языка, подразумевая ограничения в отношении других языков, в том числе и русского.

Представители русской диаспоры Крыма выражали недовольство сокращением теле-и радиовещания на русском языке, выступали против содержания учебников и «новой» истории Украины - вечной «жертвы» российской агрессии и «экспансии» (Волкогонова и Полунов, 2008: 159). Политика украинизации при В. Ющенко, ассоциировавшегося с украинским национализмом, не находила поддержки среди крымчан, вызывая у них чувство дискриминации по языковому и этническому признаку.

В то же время насильственные попытки украинского руководства ассимилировать русскоязычное население стимулировали настроения среди крымчан относительно вхождения Крыма в состав России, которые в целом сохранялись на протяжении всего постсоветского периода. Например, в 2003 и 2007 гг. русские и значительная часть украинцев, проживавших в Крыму, в будущем хотели бы видеть регион в составе Российской Федерации (Волкогонова и Полунов, 2008: 152-153). Они таким образом подрывали формирование единой украинской государственности. Русское и украинское 
население Крыма отстаивало право на свободное использование русского языка, отказывалось поддерживать украинский национализм, выступало за активное взаимодействие с Россией и сохранение исторической памяти о российском и советском прошлом.

Расширению связей с Россией способствовала деятельность местных общественнополитических организаций, наиболее активными среди которых стали Русская община Крыма, Российская община Севастополя, «За Севастополь и возрождение Черноморского флота». В своей работе они были нацелены на сотрудничество с Россией, борьбу с распространяющимся на Украине неофашизмом, сохранение самобытности многонациональной российской культуры и популяризацию истории.

Большое значение для развития и поддержания культурного и исторического наследия Крыма приобрели фонды, осуществлявшие свою деятельность при поддержке России, главным образом Москвы - фонд социальных инициатив «Москва-Крым», фонд «Русский мир» и различные проекты под эгидой российского правительства и администрации Москвы. (Островская, 2013: 132-134).

Одним из ключевых факторов, направленных на снижение роли крымчан в политической жизни Крыма, стало отстранение крымской политической элиты от ключевых постов на различных уровнях. После прихода к власти В.Ф. Януковича АР Крым приобрела первостепенное значение для Киева, и полуостров стал колонизироваться македонцами, сторонниками премьер-министра Крыма В. Джарты, являвшегося представителем донецких бизнес-структур (Никифоров, 2019: 735-736). Давление украинских властей на крымские элиты, а также политика руководства в отношении ущемления прав русскоязычного населения Крыма, сложная межнациональная ситуация заложили основы для возникновения латентного конфликта между АР Крым и Киевом. Именно активная позиция пророссийских организаций и их политических лидеров позволила крымчанам объединиться и подготовить почву для проведения референдума и вхождения Крыма в состав России.

\section{Проблема Черноморского флота}

Раздел Черноморского флота СССР между Россией и Украиной стал одним из самых болезненных вопросов в 1990-х гг. После распада Советского Союза все основные базы Черноморского флота оказались на территории украинского государства, стремившегося перевести их в свою собственность. Следует отметить, что стоимость Черноморского флота к 1992 г. составляла 80 млрд долл., и в его составе находились 835 кораблей и других судов практически всех существующих классов ${ }^{1}$.

Украина рассматривала Крымский полуостров как плацдарм для создания собственного военно-морского флота. По мнению Киева, военное наследство СССР должно было стать основой для формирования украинских военно-морских сил. В результате длительных переговоров с Россией Украине досталось $18,3 \%$ кораблей и судов Черноморского флота $\mathrm{CCCP}^{2}$. Она таким образом получила возможность создания небольших военно-морских сил и скидку на оплату российского газа (Мальгин, 2014).

Получив при разделе советского «наследства» часть флота СССР, Украина оказалась незаинтересованной в его дальнейшем развитии. Для модернизации флота и строительства военных кораблей требовались значительные финансовые средства, которые Киев оказался не в состоянии выделить. За все время существования независимой Украины было построено несколько военных кораблей и судов (Заквасин, 2017). Отсутствием весомых инвестиций в украинский морской флот можно объяснить его незначительную роль в обеспечении безопасности страны.

Отсутствие соглашений между Украиной и Россией в 1990-х гг. по вопросам, вызванным вхождением Крыма в состав украинского государства, являлось источником для дальнейших конфликтов между двумя странами. Например, в 2003 г. конфликт вокруг о. Тузла между Россией и Украиной стал следствием нерешенной проблемы делимитации границ морского пространства в Азовском и Черном морях. Договор 2003 г. о сотрудничестве в использовании Азовского моря и Керченского пролива, подписанный впоследствии между двумя странами, не определял отчетливые морские границы, что создавало возможность для возникновения новых конфликтов и провокаций со стороны Украины (Чуклина, 2019: 80-81). В итоге, вокруг базы российского Черноморского флота в Севастополе сложилась крайне напряженная ситуация. Украинская сторона постоянно провоцирова-

\footnotetext{
1 Сидорчик, А. Растоптанная гордость. Как Россия и Украина делили Черноморский флот. URL: https://aif.ru/ society/history/rastoptannaya_gordost_kak_rossiya_i_ukraina_delili_chernomorskiy_flot (дата обращения: 10.12.2020).

2 Там же.
} 
ла личный состав флота. В августе 2008 г. вспомогательные суда украинского военного флота попытались препятствовать возвращению российских кораблей в родную гавань после выполнения военных задач у берегов Абхазии и Грузии (Ракетный корабль ..., 2008).

Вопрос о базировании российского флота в Крыму до 2014 г. оставался одной из самых злободневных проблем Киева и зависел от развития политической конъюнктуры на Украине. Так, внешнеполитический курс при президентстве В. Ющенко на вступление в НАТО не соответствовал ожиданиям многих украинцев, в том числе и крымчан, что отразилось на ситуации вокруг базирования Черноморского флота. Результаты социологического исследования Киевского международного института социологии (КМИС), проведенного в феврале 2008 г., продемонстрировали сдержанное отношение украинцев в отношении к НАТО (КМИС, 2008) ${ }^{1}$. В. Ющенко, прибегая к различного рода провокациям, в свою очередь, стремился продемонстрировать влияние Украины в Крыму и вытеснять Россию, в данном случае Черноморский флот, из Севастополя. Политика Крыма по отношению к Севастополю стимулировала противодействие со стороны местного населения. В частности, крымчанам удалось помешать проведению совместных учений НАТО и Украины в Крыму в 2006 и 2008 гг. (Никифоров, 2019: 729).

Присутствие российского флота на территории Украины также являлось одним из дестабилизирующих факторов для украинского общества. По мнению националистически настроенных украинских граждан и различного рода движений, сам факт нахождения военно-морских сил России на территории независимого и суверенного государства считался незаконным нарушением прав Украины на свою территорию. Продление при президенте В.Ф. Януковиче соглашения о пребывании российского флота в Крыму до 2042 г. было позитивно оценено пророссийскими силами на полуострове, в то время как национал-демократы ожидали вывода флота России из Крыма (Никифоров, 2019: 734).

Таким образом, военно-морской флот для Украины выполнял «декоративную» функцию, показывая тем самым, что она является морским государством. База украинских ВМС в Севастополе не играла какой-либо заметной роли в обеспечении безопасности Украины.

Однако, опираясь на существование ВМС, Украина, стремясь к членству в НАТО, старалась продемонстрировать свою стратегическую значимость для Североатлантического союза и незаменимую роль в сдерживании «амбиций» России на Черном море. Вместе с тем вопрос о пребывании российского флота на Украине находился в сильной зависимости от внешнеполитических предпочтений украинских лидеров, находившихся у власти, и создал ряд проблем во взаимоотношениях двух стран. Фактически Украина до 2014 г. использовала условия базирования Черноморского флота в Севастополе в качестве инструмента шантажа РФ.

\section{Вклад Крыма в экономику Украины}

С точки зрения необходимости обеспечения своей жизнедеятельности в период до 2014 г., АР Крым находилась в экономической зависимости от Украины, что обусловлено особенностями ее географического положения, в частности, полуостровным положением и отсутствием ряда важнейших ресурсов.

Прежде всего в Крым в «украинский период» осуществлялись поставки электроэнергии с украинских АЭС, включая Запорожскую АЭС, поскольку крымская генерация обеспечивала полуостров только на $20 \%{ }^{2}$. Однако в наибольшей степени Крымский полуостров сталкивался с проблемой стабильного водообеспечения, которая была решена в советское время при помощи СевероКрымского канала. Водные ресурсы Днепра стали необходимым условием для развития сельского хозяйства Крыма и не могли быть заменены внутренними водами (Курбанов и др., 2014: 31-32).

Во второй половине 1990-х гг. общегосударственная система налогообложения Украины стала действовать и в отношении Крыма. Отток финансовых средств из республики негативно отразился на развитии региональной экономики, которая находилась в состоянии рецессии. Ситуация на полуострове усугублялась резким спадом производства до 14,1\% в 1996 г. и 24\% в 1997 г., в то время как эти значения по украинским регионам составляли 5,1\% и 1,8\% (Мальгин, 2000: 131-132). Фактически политика Киева «обескровила» экономику полуострова.

\footnotetext{
${ }^{1}$ Мнение населения Украины о проведении референдума по вступлению Украины в HATO, 14 февр. 2008 г., KMИC. URL: https://www.kiis.com.ua/?lang=rus\&cat=reports\&id=360\&page=85 (дата обращения: 02.03.2021).

2 За счет чего живет экономика Крыма, 8 февр. 2014 г., Коммерсантъ, 34. URL: https://www.kommersant.ru/doc/2418407 (дата обращения: 08.03.2021).
} 
О неэффективности экономического развития полуострова в 2001-2012 гг. свидетельствует такой показатель, как валовая добавленная стоимость (ВДС). Она позволяет оценить состояние национальной экономики, рост которой отражает увеличение бюджета, зарплаты и прибыли. Согласно данным исследователей Крымского федерального университета им. В.И. Вернадского К. и С. Онищенко, в 2001, 2004, 2007, 2008, 2010, 2011 и 2012 гг. темпы роста ВДС не опережали прирост продукта промежуточного потребления, что позволяет считать развитие экономики Крыма неэффективным. (Онищенко, Онищенко, 2016: 173-174). Следует также отметить, что объем ВРП на душу населения в АР Крым в 2004-2013 гг. был ниже среднего значения по украинским регионам ${ }^{1}$.

Украина не обладала необходимыми финансовыми ресурсами, чтобы содействовать стабильному экономическому развитию Крыма. В местный бюджет поступали ограниченные средства, которых было недостаточно для улучшения экономической ситуации на полуострове (Волкогонова и Полунов, 2008: 148).

Однако с приходом к власти В. Януковича в 2010 г. в Крым начали поступать солидные денежные средства из государственного бюджета Украины, которые стали самыми значительными за весь период пребывания полуострова в составе Украины. (Никифоров, 2019: 737).

По поручению президента Украины В. Януковича в 2010 г. была разработана «Стратегия экономического и социального развития Автономной Республики Крым на 2011-2020 годы» ${ }^{2}$. Многообещающие задачи и цели стратегии, в том числе рост ВРП АР Крым на $161,1 \%$ в течение 10 лет $^{3}$, были обусловлены сменой взгляда Киева на важность Крымского полуострова в жизни украинского государства. Однако после смерти премьер-министра Крыма В. Джарты поток финансовых средств в Крым из Киева прекратился, что привело к приостановке целого ряда важных проектов (Никифоров, 2019: 737).

Обладая мощным природно-экономическим и производственно-технологическим потенциалом, Крыму не удалось вовлечь в экономический оборот имеющиеся ресурсы. Выгодное геоэконом ическое положение Крыма является одним из конкурентных преимуществ полуострова. Благоприятный климат, разнообразный ландшафт и богатство природного потенциала (Черное и Азовское моря) обеспечивали необходимые условия для развития сельского хозяйства, рекреационного сектора и некоторых отраслей промышленности ${ }^{4}$. Отдельные секторы сельского хозяйства и отрасли промышленного производства не были характерны для материковой Украины, оставались уникальными для нее и составляли весомую долю в структуре экономики страны.

Основными специализациями Крыма в сельском хозяйстве были зерновое хозяйство, животноводство, виноградство, овощеводство и эфиромасличная отрасль (Нехайчук, 2015: 70). Так, доля Крымского полуострова в производстве винограда в начале 1990 -х гг. составляла более $30 \%$ в производстве Украины и сократилась к 2013 г. до 20,7\%. По данному показателю Крым уступал только Одесской области 5 . Добыча морских биоресурсов в Крыму, в свою очередь, давала в среднем 62-67\% от вылова на всей территории Украины, что обеспечило полуострову лидерство в данной отрасли 6 . В Крыму имелось единственное месторождение брома на территории Украины, где добывалось 50\% сырья карбоната, 50\% магниевой соли, 53,3\% флюсового известняка, $28,6 \%$ поваренной соли и $68,1 \%$ пильного камня ${ }^{7}$.

Одной из наиболее развитых отраслей промышленности на территории полуострова является химическая. Предприятия, расположенные в Крыму, выступали монополистами на рынках химической продукции на Украине и в странах СНГ. Крымская химическая продукция являлась конкурентоспособной на мировом рынке, что обусловлено наличием необходимого сырья и трудовых ресурсов (Нехайчук, 2015: 67).

Существенным потенциалом обладал рекреационный сектор Крыма. В 2013 г. в Крыму работало более 4000 мест размещения туристов - 751 зарегистрированных объектов (Нехайчук, 2015: 74). Доля количества гостиниц и аналогичных средств размещения в Крыму в 2013 г. составляла 22\% сре-

\footnotetext{
${ }^{1}$ Регіональна статистика, Держстат України. URL: https://ukrstat.org/uk/operativ/menu/menu_u/sestr.htm (дата обращения: 06.02.2021).

2 Абдуллаев, А. Р. и др. (2010) Стратегия экономического и социального развития Автономной Республики Крым на $2011-$ 2020 гг.

${ }^{3}$ Там же, сс. 75-76.

${ }^{4}$ Абдуллаев, А. Р. и др. (2010) Стратегия экономического и социального развития Автономной Республики Крым на $2011-$ 2020 гг., сс. 10-11.

${ }^{5}$ Статистичний щорічник України за 2013 pik, Держсавна служба статистики Украӥни. Київ, с. 151.

${ }^{6}$ Там же, с. 181.

${ }^{7}$ Статистичний збірник «Регіони України». Частина 1. Державна служба статистики Украӥни. Київ, сс. 24-25.
} 
ди всех подобных услуг на Украине, что превышает все другие украинские регионы ${ }^{1}$. На полуострове также располагалось наибольшее количество мест в санаториях и пансионатах на Украине - 39,7\% ${ }^{2}$.

С экономической точки зрения Крым имел в «украинский период» серьезный потенциал, однако все его возможности во время пребывания в составе Украины оставались нереализованными. Доля Автономной Республики Крым и Севастополя в экономике украинского государства в 2004-2013 гг. составляла около 3\% и 0,6-0,7\% соответственно ${ }^{3}$. Тем не менее, как отмечают 3. Олексюк и Х. Шуренберг-Фрош, «аннексия» Крыма нанесла значительный ущерб экономическому развитию Украины. Выход Крымского полуострова из состава страны привел к значительному сокращению ВВП государства более чем на 4\% и уровня благосостояния более чем на 7\% (Olekseyuk Z. and Schürenberg-Frosch H., 2019: 893). Крым был встроен в украинскую и мировую экономики, и разрыв этих связей стал причиной снижения темпов экономического развития как АР Крым с Севастополем, так и Украины. Украинское государство таким образом лишилось рынка сбыта для собственной продукции и было вынуждено закупать недостающие ресурсы у третьих стран.

\section{Заключение}

Право наций на самоопределение является одним из основополагающих принципов международного права, закрепленных Организацией Объединенных Наций. В мировой истории имеется немало примеров, когда право наций на самоопределение послужило объединением некогда разделенных народов, оказавшихся в составе разных государств. Так, Германская Демократическая Республика (ГДР) вошла в состав Федеративной Республики Германия без проведения референдума и согласия немецкого народа, проживавшего на территории ГДР. В праве наций на самоопределение не было отказано и немцам, проживавшим в Сааре, который после Второй мировой войны находился под протекторатом Франции (Шонин, 2020: 162-163).

В отличие от немецкого народа, русский народ, по представлению стран ЕС и США, не имеет права на самоопределение. Крымчане, которые на референдуме в 2014 г. выразили солидарность с крымскими властями и активно выступали за вхождение АР Крым в состав России, не могут, по мнению стран Запада, воссоединиться с Российской Федерацией. До настоящего времени на международной арене не существует значительной поддержки возвращению Крыма в состав Украины. По требованию Киева Запад с 2014 г. ввел экономические санкции против Российской Федерации.

Проблема принадлежности Крыма возникла вследствие принятия незаконного указа в 1954 г. и остается актуальной до настоящего времени. Россия проявляла пассивность в решении данного вопроса в 1990-е гг., чем, безусловно, воспользовалась Украина. Российская Федерация в 1991-1992 гг. отказалась от своего несомненного права на Крым, чтобы его в дальнейшем использовать в качестве инструмента для поддержания отношений с Киевом. Численное превосходство русского и русскоязычного населения создали все необходимые условия для дальнейшего экономического и культурного сотрудничества России с Крымом. Крымский полуостров, находясь под влиянием РФ, объективно оказывал деструктивное влияние на Украину.

Крым являлся «инородным телом» для Украины, поскольку препятствовал формированию единой государственности в стране. Формирование унитарного государства на Украине, снижение роли крымских элит, насильственная украинизация русскоязычного населения и ущемление их прав и свобод вызывали недовольство среди крымчан. Положение усугубляла противоречивая и в целом антироссийская политика Киева, который, сталкивая интересы русского и крымско-татарского населения, своими действиями стремился использовать сложную межнациональную ситуацию.

С экономической точки зрения Крым не представлял особой важности для экономики Украины. Поэтому Крымский полуостров был нужен Киеву не как экономический форпост, а как инструмент для оказания давления на Россию. Стремясь к членству в НАТО, Киев хотел показать свою стратегическую значимость и заручиться поддержкой США, вытесняя Российскую Федерацию с Крымского полуострова и, как следствие, из акватории Черного моря, ухудшая ее военностратегические позиции в регионе.

В то же время будучи единственным регионом в составе Украины с большей долей русского населения, Крым был «миной замедленного действия». Он становился препятствием на пути созда-

\footnotetext{
${ }^{1}$ Статистичний щорічник України за 2013 pik, Державна служба статистики Украӥни. Київ, с. 456.

2 Там же, с. 459.

3 Регіональна статистика, Держстат Украӥни. URL: https://ukrstat.org/uk/operativ/menu/menu_u/sestr.htm (дата обращения: 06.02.2021).
} 
ния этнически однородного украинского государства, основанного на отторжении советского прошлого и утверждении новых ценностей сквозь призму украинского национализма. Политика Украины в отношении Крыма так или иначе привела бы к конфликту, что послужило бы толчком для выхода республики из состава украинского государства и ее присоединения к России.

Киев последовательно доводил политическую ситуацию в Крыму до острого кризиса, в том числе благодаря навязываемой политике украинизации, пренебрежению к интересам русскоязычного населения, стремлению к членству в НАТО. Отсутствие заинтересованности Киева в Крыму как полноценном регионе украинского государства было компенсировано его геостратегическим положением, которое позволило использовать полуостров как средство для сближения с НАТО, играя на противоречиях с Россией.

Пророссийские настроения преобладали среди крымского населения на протяжении всего пребывания в составе Украины. Именно пророссийские организации подготовили социальную и политическую основу для присоединения Крыма к России. Данный исход был неизбежен, чему способствовали государственный переворот в феврале 2014 г. в Киеве и усиление деятельности и влияния националистических сил в стране. Потеря Крыма не стала критичной для Украины, что связано с его низкой ролью в обеспечении безопасности страны и ее экономического развития и в формировании единой украинской нации.

\section{Список литературы / References}

Вишняков, В. Г. (2011) Крылм: право и политика. Москва: ЮРКОМПАНИ. [Vishnjakov, V. G. (2011) Crimea: Law and Politics [Krym: pravo i politika]. Moskow: JuRKOMPANI. (In Russ.)].

Волкогонова, О. Д., Полунов, А. Ю. (2008) 'Политизация этничности в современной Украине: русская диаспора и межнациональные отношения в Крыму', Россия и современный мир, 2 (59), сс. 144-163. [Volkogonova, O. D., Polunov, A. Ju. (2008) 'Politization of Ethnicity in Modern Ukraine: Russian Diaspora and Interethnic Relations in Crimea' [Politizacija jetnichnosti v sovremennoj Ukraine: russkaja diaspora $\mathrm{i}$ mezhnacional'nye otnoshenija v Krymu], Rossija $i$ sovremennyj mir, 2 (59), pp. 144-163. (In Russ.)].

Ерохина, О. В. (2016) 'Проблемы национально-государственной самоидентификации крымчан, регулирования межэтнических отношений в Крыму, политическая и социальная адаптация крымчан к жизни в составе Российской Федерации', Наука. Общество. Оборона, 2 (7). URL: https://cyberleninka.ru/article/n/problemy-natsionalnogosudarstvennoy-samoidentifikatsiikrymchan-regulirovaniya-mezhetnicheskih-otnosheniy-v-krymu-politicheskaya-i/viewer (дата обращения: 10.03.2021). [Erohina, O. V. (2016) 'Problems of National-state Selfidentification of Crimeans, Regulation of Interethnic Relations in Crimea, Political and Social Adaptation of Crimeans within the Russian Federation' [Problemy nacional'no-gosudarstvennoj samoidentifikacii krymchan, regulirovanija mezhjetnicheskih otnoshenij $\mathrm{v}$ Krymu, politicheskaja i social'naja adaptacija krymchan $\mathrm{k}$ zhizni v sostave Rossijskoj Federacii], Nauka. Obshhestvo. Oborona, 2 (7). Available at: URL: https://cyberleninka.ru/article/n/problemy-natsionalnogosudarstvennoy-samoidentifikatsii-krymchan-regulirovaniya-mezhetnicheskihotnosheniy-v-krymu-politicheskaya-i/ viewer (Accessed: 10 March 2021). (In Russ.)]. DOI: 10.24411/2311-17632016-00011.

Заквасин, А. (2017) 'По живому: 20 лет назад Россия и Украина разделили Черноморский флот СССР', ТВ-Новости. URL: https://russian.rt.com/ussr/article/ 394322-20-let-nazad-rossiya-ukrainarazdel-chernomorskiy-flot-sssr (дата обращения: 03.03.2021). [Zakvasin, A. (2017) Like a Knife: Russia and Ukraine Divided the USSR Black Sea Fleet 20 Years Ago' [Po zhivomu: 20 let nazad Rossija i Ukraina razdelili Chernomorskij flot SSSR], TV-Novosti. Accessed: 3 March 2021 (In Russ.)].

Курбанов, А. Х. и др. (2014) 'Интеграция экономики Крыма в российскую экономическую систему: состояние и перспективы', Известия СанктПетербургского государственного экономического университета, 4 (88). cc. 30-37. [Kurbanov, A. H. et al. (2014) 
'Integration of Crimea's Economy into the Russian Economic System: State and Perspectives' [Integracija jekonomiki Kryma v rossijskuju jekonomicheskuju sistemu: sostojanie i perspektivy], Izvestija Sankt-Peterburgskogo gosudarstvennogo jekonomicheskogo universiteta, 4 (88), pp. 30-37. (In Russ.)].

Мальгин, А. В. (2000) Крымский узел. Очерки политической истории Крымского полуострова 1989-1999. Симферополь: Новый Крым. [Mal'gin, A. V. (2000) The Crimean Knot. Essays on the Political History of the Crimean Peninsula 19891999 [Krymskij uzel. Ocherki politicheskoj istorii Krymskogo poluostrova 1989-1999]. Simferopol: Novyj Krym. (In Russ.)].

Мальгин, А. В. (2012) “«Русский Крым» в посторанжевой Украине: новые реалии старые проблемы', Boпросы развития Kpыммa, 16, сc. 333-347. [Mal'gin, A. V. (2012) 'Russian Crimea in Post-Orange Ukraine: New Realities - Old Problems' [«Russkij Krym» V postoranzhevoj Ukraine: novye realii - starye problemy], Voprosy razvitija Kryma, 16, pp. 333-347. (In Russ.)].

Мальгин, А. В. (2014) 'Крымский узел. Что привело к «Русской весне»-2014?', Россия в глобальной политике, 2. URL: https://globalaffairs.ru/articles/krymskijuzel-chto-privelo-k-russkoj-vesne-2014/ (дата обращения 10.04.2021). [Mal'gin, A. V. (2014) 'The Crimean Knot: What did lead to the "Russian Spring"-2014?' [Krymskij uzel. Chto privelo k «Russkoj vesne»-2014?], Rossija v global'noj politike, 2. Available at: https://globalaffairs.ru/articles/krymskijuzel-chto-privelo-k-russkoj-vesne-2014/ (Accessed: 10 April 2021). (In Russ.)].

Мацузато, К. (2009) Крым и Николаевская область. T. 3. Sapporo: Slavic Research Center, Hokkaido University [Macuzato, K. (2009) Crimea and Nikolayevskaya Oblast [Krym i Nikolaevskaja oblast']. V. 3. Sapporo: Slavic Research Center, Hokkaido University. (In Russ.)].

Нехайчук, Д. В. и др. (2015) Долгосрочные тренды развития Крыма: соииальноэкономический аспект. Симферополь: Крымский институт бизнеса. [Nehajchuk, D. V. i dr. (2015) Long-term Trends of the Crimea's Development: Socio-economic Aspect [Dolgosrochnye trendy razvitija Kryma: social'nojekonomicheskij aspect]. Simferopol': Krymskij institut biznesa. (In Russ.)].

Никифоров, А. Р. (2019) 'Крым в дестабилизирующейся Украине: от «оранжевой революции» до Евромайдана. 2004-2014' в: Юрасов, В. А. (отв. ред.) История Крыма, Т. 2. Москва: Кучково поле, сс. 725-740. [Nikiforov, A. R. (2019) 'Crimea in Destabilizing Ukraine: from the "Orange Revolution" to Euromaidan. 2004-2014' [Krym v destabilizirujushhejsja Ukraine: ot «oranzhevoj revoljucii» do Evromajdana. 2004-2014] in: Jurasov, V. A. (otv. red.) History of Crimea [Istorija Kryma], V. 2. Moskow: Kuchkovo pole, pp. 725-740. (In Russ.)].

Онищенко, К. Н., Онищенко, С. К. (2016) 'Оценка эффективности роста экономики Крыма за 2001-2012 гг.', Интеграция Республики Крым в систему экономических связей Российской Федерачии: теория и практика управления, сс. 173-174. [Onishhenko, K. N., Onishhenko, S. K. (2016) 'Assessment of Efficiency of the Crimea's Economic Growth in 2001-2012' [Ocenka jeffektivnosti rosta jekonomiki Kryma za 2001-2012 gg.], Integracija Respubliki Krym $v$ sistemu jekonomicheskih svjazej Rossijskoj Federacii: teorija i praktika upravlenija, pp. 173-174. (In Russ.)].

Островская, И. В. (2013) 'Современное состояние общественных организаций русской диаспоры Автономной Республики Крым', Наука о человеке: гуманитарные исследования, 2 (12), сс. 131136. [Ostrovskaja, I. V. (2013) 'The Current State of Public Organizations of the Russian Diaspora of the Autonomous Republic of Crimea' [Sovremennoe sostojanie obshhestvennyh organizacij russkoj diaspory Avtonomnoj Respubliki Krym', Nauka o cheloveke: gumanitarnye issledovanija], Nauka o cheloveke: gumanitarnye issledovanija, 2 (12), pp. 131-136. (In Russ.)].

Ракетный корабль «Мираж» вернулся от берегов Грузии в Севастополь (2008) РИА Новости. URL: https://ria.ru/ 20080822/150585022.html (дата обращения: 20.02.2021). [The Rocket Ship "Mirage" Returned from the Coast of Georgia to Sevastopol (2008) [Raketnyj korabl' «Mirazh» vernulsja ot beregov Gruzii v Sevastopol']. RIA Novosti. (In Russ.)]. 
Чуклина, Э. Ю. (2019) 'Проблема делимитации Азовского моря: ретроспективный взгляд и варианты решения', Крылмский научный вестник, 4, сс. 77-84. [Chuklina, Je. Ju. (2019) 'The Problem of Delimitation of the Sea of Azov: a Retrospective View and Possible Solutions' [Problema delimitacii Azovskogo morja: retrospektivnyj vzgljad i varianty reshenija], Krymskij nauchnyj vestnik, 4, pp. 77-84. (In Russ.)].

Шонин, Н. Е. (2020) 'Принцип равноправия и самоопределения народов и политика двойных стандартов', Тенденции развития науки и образования, 65-2, cc. 159-164. [Shonin, N. E. (2020) 'The Principle of Equality and Selfdetermination of Peoples and the Policy of Double Standards' [Princip ravnopravija i samoopredelenija narodov i politika dvojnyh standartov], Tendencii razvitija nauki i obrazovanija, 65-2, pp. 159-164. DOI: 10.18411/lj-09-2020-77. (In Russ.)].

Olekseyuk, Z., Schürenberg-Frosch, H. (2019) 'Ukraine's unconsidered losses from the annexation of Crimea: What should we account for in the DCFTA forecasts?', Review of Development Economics, V. 23, 2, pp. 877-901. DOI:10.1111/rode.12574.

Статья поступила в редакщию: 03.05.2021

Статья поступила в редакцию повторно, после доработки: 20.07.2021

Статья принята к печати: 30.07.2021

\title{
POLITICAL MEANING OF CRIMEA FOR UKRAINE IN 1991-2014
}

\section{S. E. Kievec}

S. E. Kievec, postgraduate student, Graduate School of International Relations and Foreign Regional Studies, National Research University Higher School of Economics, Russia, Moscow.

E-maiL: KievecSemyon@yandex.ru (ORCID: 0000-0002-8943-4416).

\begin{abstract}
The article considers Crimea's political meaning within Ukraine in 1991-2014 and analyzes the main challenges in Kyiv-Simferopol relations. Based on the extensive database, the conclusion concerning the illegal joining of the Republic of Crimea to Ukraine in 1990s is made. The article analyzes the destructive influence of the Russian and Russian-speaking population of the peninsula on the Ukrainian statehood formation. The role of the pro-Russian organizations and the Russian-speaking population in Crimea's breakaway from Ukraine is defined. The author studies the role of the Black Sea Fleet for Ukraine used as a tool to impose pressure on Russia and to increase its power in the eyes of NATO. Crimea's contribution to the Ukrainian economy is assessed and the key branches of industry and agriculture of the Autonomous Republic of Crimea are identified. The article concludes that the conflict between Kyiv and Simferopol and Crimea's accession to Russia was inevitable and was predetermined by the controversial policy of the Ukrainian authorities. Absence of importance of the Crimean Peninsula for Ukraine from the perspective of economic development, a single Ukrainian nation formation and security was also traced.
\end{abstract}

Keywords: Autonomous Republic of Crimea; Ukraine; Russia; annexation; Russian-speaking population; Black Sea Fleet; economy. 